\title{
Substantiation and optimization of quantity and type of mechanical cleaners supplied to milk pipe when rinsing milking units
}

\author{
Vladimir V. Kirsanov ${ }^{1}$, Vladimir Yu. Matveev ${ }^{2}$, Maxim M. Maslov², Williams P. Zaikin², and Maxim P. Erzamaev," \\ ${ }^{1}$ Federal Scientific Agroengineering Center VIM, Moscow, 109428, Russia \\ ${ }^{2}$ Nizhny Novgorod State University of Engineering and Economics, Knyaginino, 606340, Russia \\ ${ }^{3}$ Samara State Agrarian University, Samara, 446442, Russia
}

\begin{abstract}
The article presents the results of production tests of three designs of mechanical cleaners intended to increase the efficiency of sanitary processing of milking installations. As a result of the experiment, the optimal number of mechanical cleaners and their type were determined. The optimization criterion was the total microbial number (KMAFAnM) obtained as a result of seeding on the nutrient medium of washings from the inner surface of the milk line. As a result of the experiment, it was determined that the optimal result is achieved by sanitizing a milking unit with 4-5 mechanical cleaners with a cleaning surface of bristles.
\end{abstract}

\section{Introduction}

Milk production is one of the largest and most promising sectors of the agricultural sector. Annual positive dynamics mark the production of this product and, according to forecasts of the Russian Ministry of Agriculture, should reach 31.6 million tons in 2020 [1].

Together with increasing the amount of milk produced, each producer strives to improve its quality, because its price in the market depends on the physicochemical parameters of milk. It should be noted that the main two groups of factors affect the quality parameters of milk:

- providing production (lactation period, breed of cows, their health status, conditions of detention, diet and quality of feed);

- ensuring safety (technology of milking cows and primary milk processing).

Our research team is directly involved in ensuring the safety of milk after dispensing.

The main reason for reducing the quality of milk is the activity of microorganisms, the bulk of which gets into it as a result of contact with the environment and the internal surfaces of the milking equipment.

Milk is a favourable breeding ground for bacteria and microorganisms. For getting an idea of the quality of milk and its nutritional value, it is examined for purity, density, acidity, fat and protein, as well as bacterial contamination. The negative effect of bacterial contamination on milk quality is noted in published works of domestic and foreign researchers [2-4].

A significant impact on the bacterial contamination of milk is exerted by the sanitary state of the milking equipment and its timely cooling (Table 1) [5]. If the sanitary condition of the milking equipment is unsatisfactory, then further cooling of the seeded milk will not give the expected results.

The maintenance rules $[6,7]$ provide for daily maintenance of ETO milking machines (before milking, during milking and after milking), maintenance of TO-1 (after 180-200 hours of operation) and T0-2 (after 2000 -2500 hours of work).

The most important operation to care for milking equipment is to flush it. If it is not enough to thoroughly rinse the milking equipment, then moving along the milking unit, the bacterial contamination will overgrow, and the milk obtained will be infected.

Table 1. The main causes of bacterial contamination of milk

\begin{tabular}{|c|l|c|}
\hline No. & $\begin{array}{l}\text { Source of bacterial } \\
\text { insemination }\end{array}$ & $\begin{array}{l}\text { The number of } \\
\text { bacteria in } 1 \mathrm{ml}\end{array}$ \\
\hline 1 & $\begin{array}{c}\text { The first trickles of milk are } \\
\text { not seized 100 }\end{array}$ & $100-1000$ \\
\hline 2 & Air environment in the barn & $100-1500$ \\
\hline 3 & Contaminated udder & $500-15000$ \\
\hline 4 & $\begin{array}{c}\text { Inadequate washing and } \\
\text { disinfection of milking and } \\
\text { dairy equipment }\end{array}$ & 500000 \\
\hline 5 & Inadequate milk cooling & 5000000 \\
\hline
\end{tabular}

The concept of "sanitization", as noted by V. Moor [2], includes a set of manipulations aimed at destroying pathogens and reducing the number of non-pathogenic microorganisms to such a level that they do not significantly affect the quality of milk during repeated

Corresponding author: erzamaev_mp@mail.ru 
use of equipment.

Washing milking equipment should ensure the removal of various kinds of contaminants from the surface in contact with milk.

Moor V. [2], established that for high-quality disinfection of a surface cleaned of residues of milk contaminants (especially fat), it is sufficient to contact the disinfectant solution with it for 2 minutes. With the existing technology of multi-stage washing of milking machines, even with more prolonged disinfection, the cleanliness of the treated surface remains low. The reason for this is the insufficient quality of cleaning its surfaces from contamination, after which a protein-fat film remains on the surface of the equipment, which protects bacteria from the action of disinfectants.

After washing the bath, collector, the first and second milk pipelines with an alkaline solution, and the milk
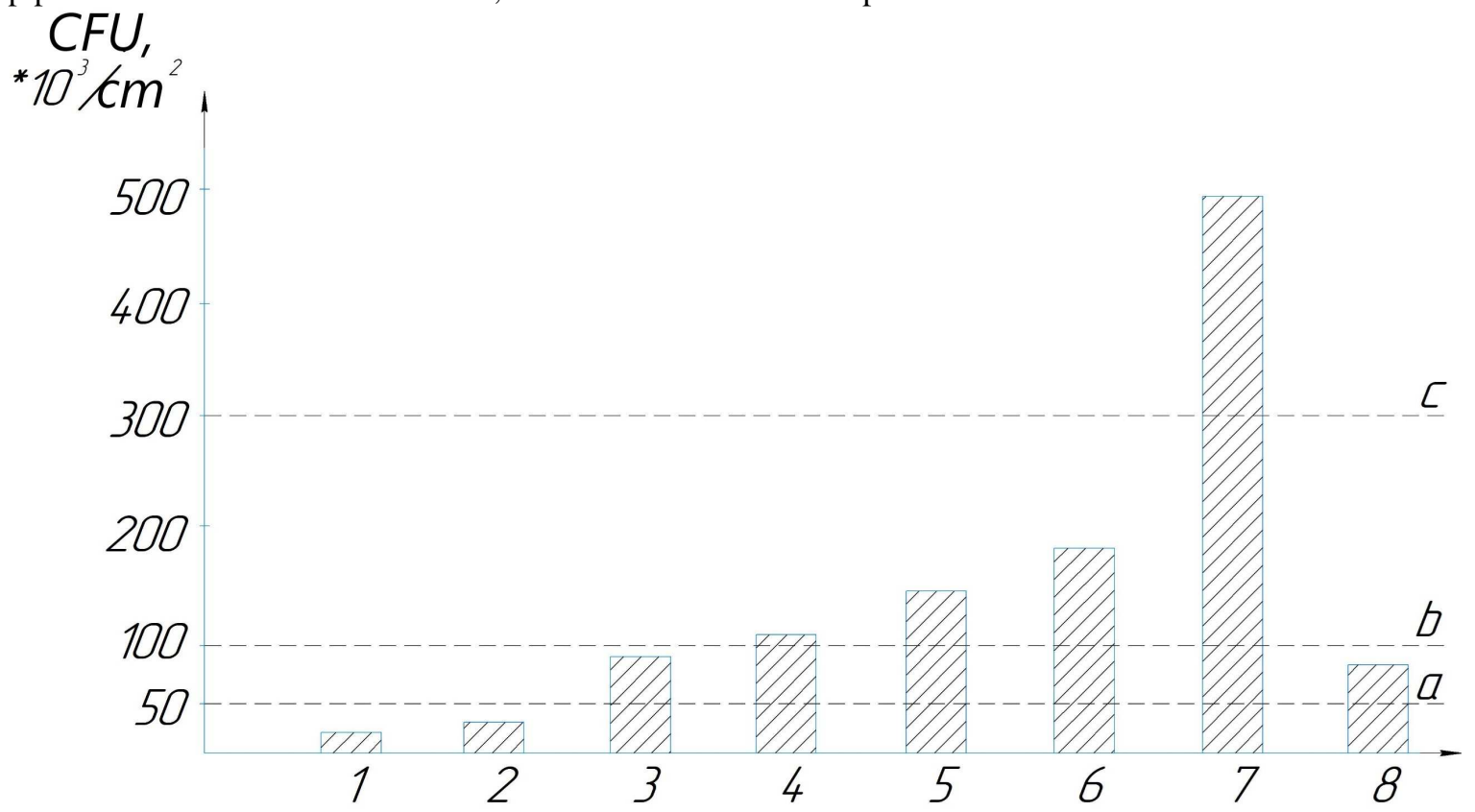

Fig. 1. The level of bacterial contamination of the surfaces of the milk piping systems of the UDM-200 milking unit (thousand pieces per $\mathrm{cm}^{2}$ ): 1 - bath; 2 - collector; 3 - the beginning of the first line of the milk pipeline; 4 - end of the first line of the milk line; 5 the beginning of the second line of the milk pipeline; 6 - end of the second line of the milk line; $7-$ milk dispenser; $8-$ milk receiver; $a$ is the upper limit of the level of bacterial contamination of equipment; $b$ - the upper limit of the level of bacterial contamination of milk in the EU; c - the upper limit of the level of bacterial contamination of milk in the Russian Federation.
Currently, the degree of purity of milking equipment is determined using visual and bacteriological control [8].

During a visual inspection of the equipment, attention is paid to the condition of the main components: milking cups, collector, milk hose, covers of milking buckets, viewing devices, milk pipe, filter, detected on a controlled surface, it is prohibited to use this equipment without thorough cleaning.

Bacteriological control, the purity of milking installations is carried out using. GOST 9225-84, as well as the "Sanitary Rules" [8].

The milk pipe is the largest part of the volume of contact with the surface of milk dispensed. That is why flushing the milk line should pay special close attention to all other nodes of the milking equipment.

The technical regulations set the content of milk cooler and milk pumps. If contamination film is samples were taken for bacterial contamination. As a result, the following values were obtained for bacteriological contamination of the surfaces of individual elements of the milk distribution system of the UDM-200 milking unit (Fig. 1).

With an acceptable level of bacteriological contamination of the surfaces of milk systems after washing, it was not exceeding 50 thousand microorganisms in $1 \mathrm{~cm}^{2}$. Only in two cases, when determining bacteriological contamination on the surfaces of the bath and collector, the value of this indicator was lower than permissible. In all other cases, the level of bacteriological contamination exceeded the permissible level. This fact necessitates the identification of the causes of ineffective washing of surfaces and the development of measures to eliminate deficiencies. dispenser and milk receiver with an acid solution,

KMAFAnM and somatic cells to not more than $5 * 10^{5}$ $\mathrm{CFU} / \mathrm{cm}^{3}$ (g) [9].

In order to maintain the regulated sanitary state of milking equipment, several measures are provided for by the Sanitary Rules, but this is not always enough [8, 1012].

A decrease in the level of bacterial contamination leads to an increase in shelf life, the preservation of nutrients and an increase in the safety of milk produced.

\section{Materials and methods}

As the object of study, the milking installation of the commercial dairy farm SPK Zarya, located in the village of Oghibovka, Pilninsky district, Nizhny Novgorod region, was chosen. The milking unit at this farm is equipped with two separate milk circuit, which reduced the time of the study. 
The study aimed to determine the effectiveness of the use of various amounts and types of mechanical cleaners in the sanitary treatment of a milking unit.

The supply of mechanical cleaners was carried out manually by loading them at the beginning of the milk line during operation of the washing machine for the milking unit in the cycle of circulating washing of the washing-disinfecting solution.

Foam wad and two constructions of the developed mechanical cleaners with a cleaning surface made of foam rubber and bristles acted as mechanical cleaners (Fig. 2) [13, 14].

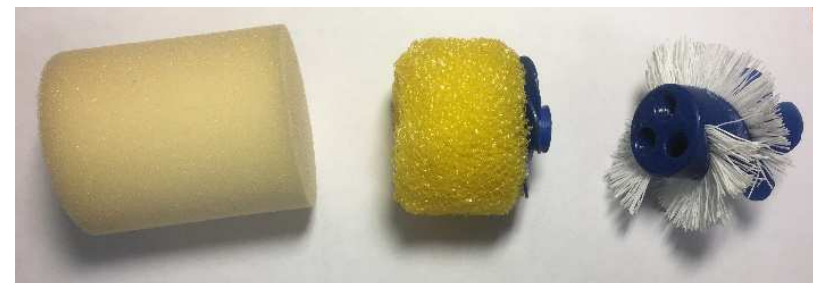

a)

b)

c)

Fig. 2. Types of mechanical cleaners of the inner surface of the milking unit used for sanitation: a) foam wad; b) a mechanical cleaner with a foam rubber cleaning surface; c) a mechanical cleaner with a cleaning surface of bristles.

Foam wads are used on most modern milking installations. However, their number is usually limited to one, and they serve more to remove residual milk. However, they also have a cleaning effect due to mechanical effects on the surface. In order to determine this effect, they are added to the experiment.

Also, in the experiment involved two options for mechanical cleaners with active working bodies. These mechanical cleaners are developed based on the Nizhny Novgorod State University of Engineering and Economics. They are a cylindrical body on which the cleaning element is located, rigidly connected to the propeller, in order to reduce the linear speed of the device and increase the speed of rotation in the body of the mechanical cleaner made spiral channels. The role of the cleaning element is either foam rubber or synthetic bristles.

The number of mesophilic aerobic and facultative anaerobic microorganisms (KMAFAnM or total microbial number, TMP) was chosen as a criterion for assessing effectiveness. This indicator was determined using the Biocontrol rapid test. The test is a sealed plastic test tube with two test surfaces built into the cap. In order to increase the accuracy of this experiment, a test with two identical test surfaces on which pink agar (OMC / OMC) was applied and selected. Sampling was carried out according to the instructions in the following sequence:

- a washout was taken in a volume of $25 \mathrm{ml}$ directly into a plastic test tube. Sampling was carried out by flushing from the inner surface of the milk line near the receiving tank;

- the test was immersed for 10 seconds in a test tube with flushing and shaken for even distribution;
- after the indicated time, the liquid was removed and the test, the lid tightly closed, was placed in a cabinet, protected from sunlight and at a constant temperature of $22 \pm 2{ }^{\circ} \mathrm{C}$ for 24 hours. After the specified time, the results were evaluated.

The evaluation was carried out by comparing the density of the colonies on the plate. Tests were compared with reference photographs from the instructions with subsequent interpolation of the results.

\section{Results}

The experiment was planned to determine the optimal amount of supplied mechanical cleaners and their type, as well as to identify their mutual influence on the quality of cleaning the inner surface of the milk pipeline [15].

The influence of the following factors was investigated: the amount of supplied mechanical cleaners and their type (Table 2) on the level of bacterial seeding, in particular, KMAFAnM (TMP).

The value of factor $\mathrm{x} 1$ was taken from the analysis of previous studies and had a value of 1-6 with a variation interval equal to 1 . The value of factor $x_{2}$ was taken to test mechanical cleaners with active working bodies in comparison with the traditionally used foam rubber wads.

The number of mesophilic aerobic and facultative anaerobic microorganisms (KMAFAnM) was determined as the optimization criterion, determined through flushing from the inner surface of the milk line of the milking unit immediately before the milking working cycle during three-time milking (Fig. 3).

Table 2. Intervals and levels of variation of factors studied in substantiating the type and quantity of mechanical cleaners

\begin{tabular}{|c|c|c|c|}
\hline \multirow{2}{*}{\multicolumn{2}{|c|}{$\begin{array}{c}\text { Name and } \\
\text { designation of } \\
\text { the factor } \\
\begin{array}{c}\text { Designation of } \\
\text { factors }\end{array} \\
\end{array}$}} & $\begin{array}{l}\text { The number of } \\
\text { supplied } \\
\text { cleaners N, pcs }\end{array}$ & Type of cleaner \\
\hline & & $x_{1}$ & $x_{2}$ \\
\hline \multirow[b]{2}{*}{ 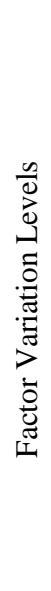 } & 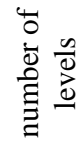 & 6 & 3 \\
\hline & 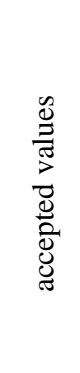 & $\begin{array}{l}1 \\
2 \\
3 \\
4 \\
5 \\
6\end{array}$ & $\begin{array}{l}\text { 1- Foam Wad } \\
\text { 2- Mechanical } \\
\text { cleaner with a foam } \\
\text { cleaning surface } \\
\text { 3- Mechanical } \\
\text { cleaner with the } \\
\text { bristle cleaning } \\
\text { surface }\end{array}$ \\
\hline
\end{tabular}




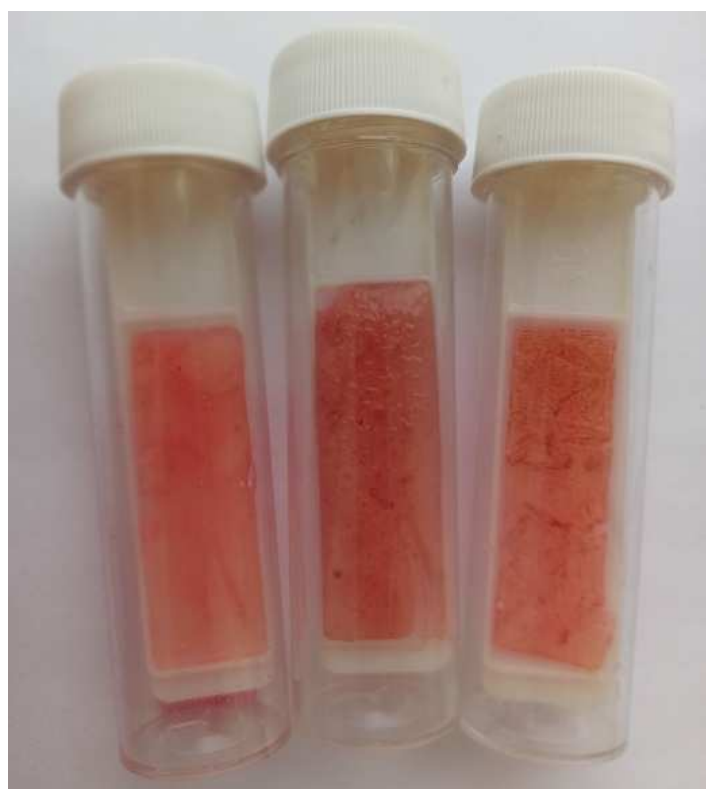

Fig. 3. Sample samples using the rapid microbiological test "Biocontrol."
For process the results, the Statgraphics 18 software package was used [16]. When determining the significance of factors, the factor $x_{1} x_{2}$ turned out to be insignificant.

The criterion $p$ evaluated the significance of the effects, large 0.05 , have the following effects: $x_{1}, x_{2}, x_{1}^{2}$, $x_{2}{ }^{2}$. The paired interaction $x_{l}$ is of the most significant importance.

After eliminating insignificant factors, a regression model was obtained with a $95 \%$ confidence probability: $y=3,45667-1,29036 * x_{1}+2,6375 * x_{2}+0,1325 * x_{1}^{2}-0,8375 * x_{2}{ }^{2}$ (1)

The adequacy of the regression model was assessed by the coefficient of determination $\mathrm{R} 2$, which was 93.12\%. That is, the constructed model may be applicable to describe the process under study.

Based on the obtained regression model, response surfaces were constructed that characterize the influence of the studied factors on the performance of mechanical cleaners (Fig. 4).
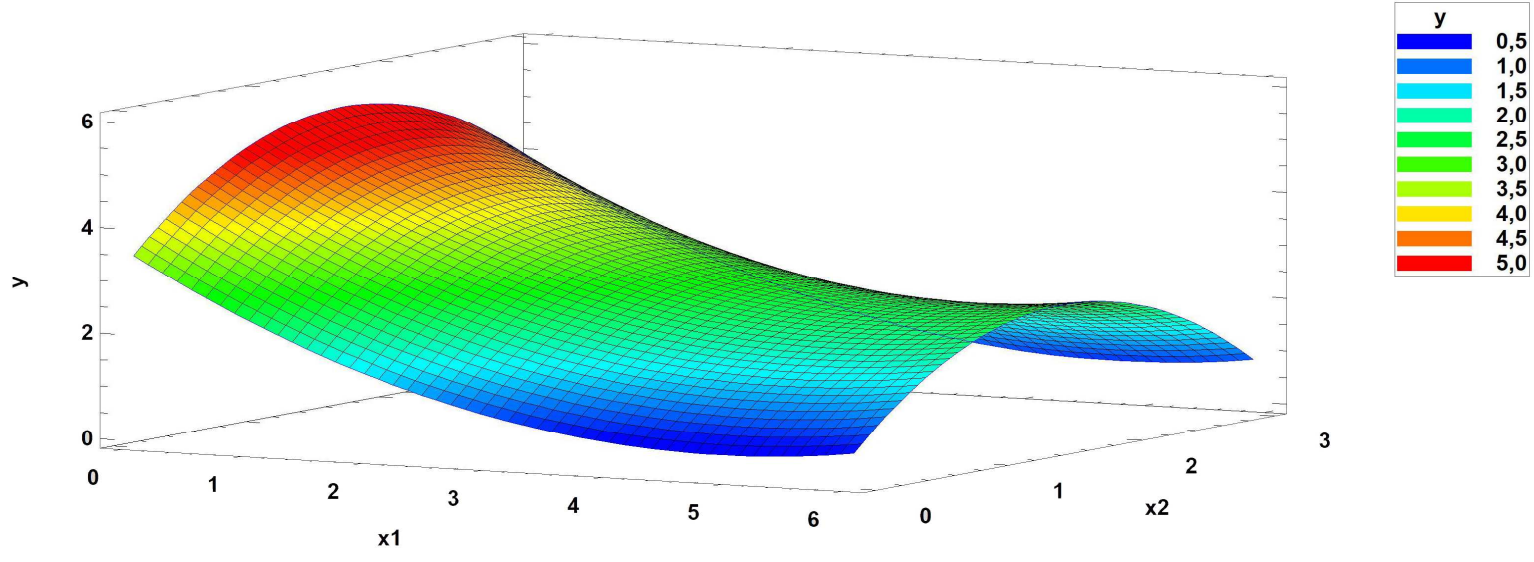

Fig. 4. The response surface, characterizing the influence on the criterion of optimization factors: $\mathrm{y}-$ level KMAFAnM, CFU / $\mathrm{cm}^{2} *$ $10^{5} ; \mathrm{x}_{1}-$ the number of supplied mechanical cleaners, pcs; $\mathrm{x}_{2}$ - type of mechanical cleaners.

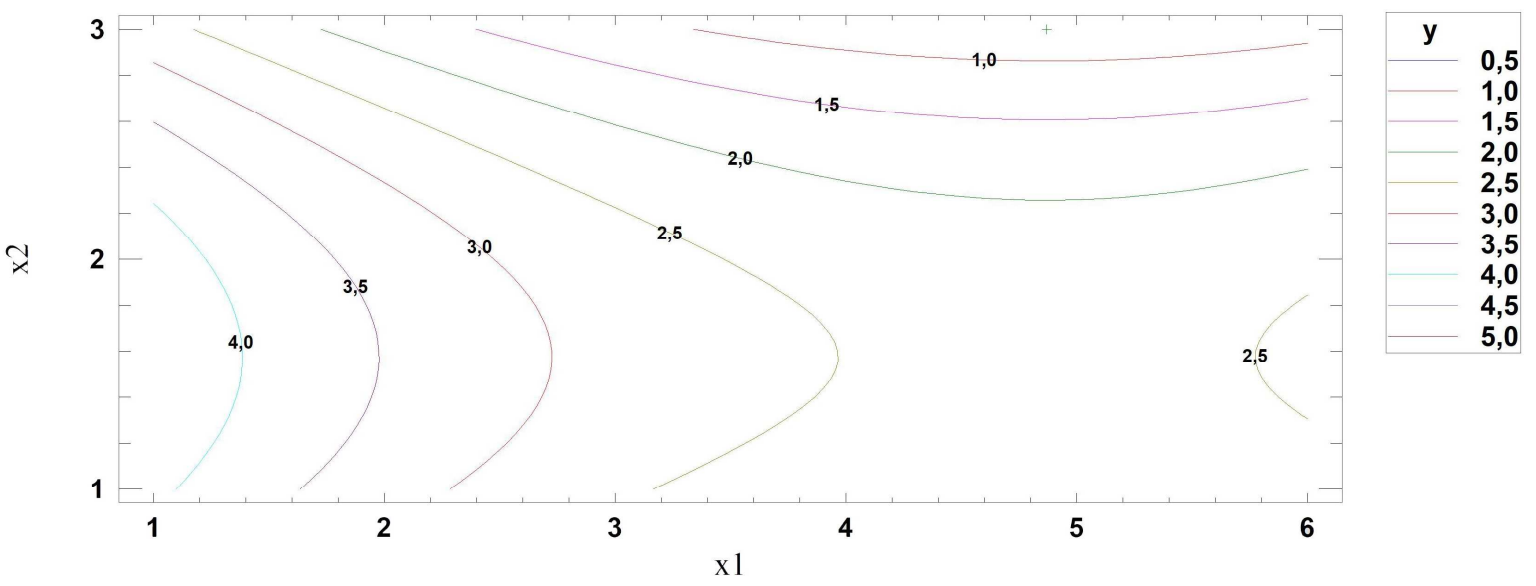

Fig. 5. Two-dimensional cross-section of the response surface: $\mathrm{y}-$ level KMAFAnM, CFU $/ \mathrm{cm}^{2} * 10^{5} ; x_{1}-$ the number of supplied mechanical cleaners, pcs; $x_{2}$ - type of mechanical cleaners 
From the analysis of the surface (Fig. 4), it can be seen that with an increase in the number of supplied cleaners (factor $x_{1}$ ), the optimization criterion $y$ decreases. It is also worth noting that the effectiveness of a mechanical cleaner with a foam rubber cleaning surface $\left(x_{2}=2\right)$ is lower compared to a mechanical cleaner with a cleaning surface made of bristles $\left(x_{2}=3\right)$.

The minimum level of bacterial seeding is possible with the maximum number of supplied cleaners with active working bodies from bristles.

However, it should be noted that the optimal values of the factors $x_{1}$ and $x_{2}$ are 5 mechanical cleaners with a cleaning surface of bristles. Graphically, the optimum point can be determined from the contour of the calculated response surface (Fig. 5).

\section{Conclusion}

Thus, as a result of the study, the following conclusions can be drawn:

1. The use of mechanical cleaners for circulating washing of milking units is an effective measure. It allows reducing the level of bacterial contamination of the inner surface of the milking unit by more than $30 \%$.

2. The maximum cleaning effect is achieved by applying six mechanical cleaners. However, due to a decrease in efficiency, their optimal number is 4-5 pcs.

3. Of the three structures of mechanical cleaners under consideration, the mechanical cleaner with the bristle cleaning surface showed the greatest efficiency.

The use of mechanical cleaners in conjunction with traditional methods of sanitizing milking machines allows KMAFAnM being reached significantly below the threshold values established by regulatory documents. Therefore, when using mechanical cleaners, it becomes possible to reduce the duration of the sanitary treatment and the volume of the washing-disinfecting solution.

\section{References}

1. In 2020, Russia can increase milk production to 31.6-32 million tons, according to the Ministry of Agriculture, Finmarket Information Agency (2020) Available http://www.finmarket.ru/news/5161112

at:

2. V. Moor, Sink and disinfection in the dairy business (Pishchepromizdat, Moscow, 1957) 163 p.

3. G.P. Degtyarev, Detergents and disinfectants and product quality, Dairy industry, 6, 12-13 (1996)

4. A.M. Zhmyrko, Substantiation of parameters and operating modes of the milk system washing system for milking installations for milking cows installs, candidate dissertation (Zernograd, 2005) 159 p.

5. N.G. Belenky, N.S. Koroleva, I.P. Danilenko, V.V. Molochnikov, Sanitary and hygienic quality of milk procured and ways to improve it, in: Improving the quality of milk and dairy products (Kolos, Moscow, 1980) pp. 27-37

6. S.V. Melnikov, Technological equipment of livestock farms and complexes (Agropromizdat, Leningrad, 1985) 640 p.

7. Milking installations with milk pipeline UDM-100, UDM-200. Technical description and instruction manual (2005) 49 p.

8. Sanitary rules for the care of milking units and milk utensils, monitoring their sanitary condition and sanitary quality of milk. Approved by the Gosagroprom of the USSR in agreement with the Ministry of Health of the USSR on September 29, 1986. $10 \mathrm{p}$.

9. Technical regulations of the Customs Union "On the safety of milk and dairy products" (TR TS 033/2013) Available at: http://docs.cntd.ru/document/499050562

10. S.A. Kostyukevich, Improved technology for washing milking and dairy equipment, Bull. of Kursk State Agricultural Academy, 6, 35-38 (2017)

11. M.V. Baranovsky, A.S. Kurak, T.N. Ageichik, Ways to improve the sanitary quality of milk, Zootechnical Science of Belarus, 38, 315-320 (2003)

12. V.Yu. Matveev, V.P. Zaikin, M.M. Maslov, Development of a functional-morphological model of a system for sanitizing a milking unit, Agricultural Scientific J., 3, 85-90 (2020)

13. Device for cleaning the milk line of a milking unit: application $2020105316 \mathrm{RF}$ as of 20 April 2020

14. V.V. Kirsanov, V.Y. Matveev, M.M. Maslov, W.P. Zaikin, M.P. Erzamaev, Influence of devices for cleaning the milk pipes of the milking units on the ecology of milk production, IOP Conference Series: Earth and Environmental Science, 012075 (2020)

15. S.M. Gaidar, Planning and analysis of the experiment: a textbook (Rosinformagroteh, Moscow, 2015) $548 \mathrm{p}$.

16. V.A. Kravchenko, A.A. Atamanov, Determination of the optimal mode of evaporation of the waterethanol extract of Sorbus aucuparia, In: Young scientists in solving urgent problems of science. Coll. of mater. of the All-Russian sci.-pract. conf. of students, graduate students and young scientists (2019) pp. 163-164

\footnotetext{
*Corresponding author: erzamaev_mp@ mail.ru
} 